\title{
MYCOLOGICAL PROFILE OF FRESH WATER FISH
}

\author{
Yehia, N. and I. Aman \\ Dept. Food Hygiene, Fac. of Vet. Med. Kafr El-Sheikh, Tanta Univ
}

\begin{abstract}
Owing to the increasing importance of fish as one of the most important food staffs, and constitutes the chief source of protein in the diet of wide range of peoples, and also owing to the wide spread distribution of mould and yeasts which comprise a large group of microorganisms and may contaminate foods, resulting in serious effects on human health. the present study was planned to detect the incidence of mould and yeasts contamination of fresh water fish (Tilapia nilotica) in El-Gharbia and Kafr El-Sheikh Governorates. A total of 180 random samples of (Tilapia nilotica) were collected from El-Gharbia and Kafr El-Sheikh (90 of each) the obtained results indicates that $44.4 \%$ and $50 \%$ of El-Gharbia and Kafr El-Sheikh samples were contaminated by mould and yeasts respectively. Moreover, the isolated strains of mould and yeasts were identified and recorded in different percents. The public health significance of isolated microorganisms were also discussed.
\end{abstract}

\section{INTRODUCTION}

Fungal contamination of fish is considered as one of the important causes of fish spoilage which led to off flavor, offensive odour and unpalatable taste as well as severe economic losses (Ward and Baaj, 1988), while El-Shinawy et al. (1994) revealed that toxic metabolites were produced by most types of fungi, leading to direct hazard to human health due to its mutagenic, carcinogenic, tetratogenic and hepatotoxic effects.

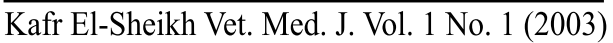


Subacute levels of mycotoxins were responsible for liver disease and organ damage. While high mycotoxin levels could lead to liver cancer (Bullerman, 1979).

It was also reported that yeast and mould were widely distributed in nature, on plants, skin, feather, alimentary tract and soil which constitute an important reservoir and through which mould and yeasts can be disseminated into food, causing sever hazards to human health as Candida albicans which is responsible for thruch, white patches in the mouth, throat and dermatitis of palms, as well as meningitis, ophthalmitis, osteomyelitis and other local infections in childrens and infants as recorded by Wilson et al. (1981), Rippon (1982) and Shaltout and Edris (1999). While Trichosporon species may be lead to occasional opportunistic invasion of mucous membrane and skin, while Saccharomycesis is the main agent responsible for occasional cases of thrush and vaginitis, it was also recorded that there a strong relationship between cryptococcal infection and some debilitating disease as leukemia and malignant lymphoma (Finegold and Martin, 1982).

The mould count is used as index for the proper sanitation and high quality fish. Mould can assist in the fish putrefaction, they may impart a mouldy odour and taste of food stuffs, moreover mould can grow over an extremely wide range of temperature. Therefore, mould may be detected on all food at almost any temperature (Frazier and Wasthoff, 1983 and Shaltout, 1996).

So, the aim of this work is to throw a light on the incidence of mould and yeasts in fresh water fish (Tilapia nilotica), isolation, identification and its public health significance.

\section{MATERIALS \& METHODS}

\section{I.Collection of samples:}

A total of 180 random samples of fresh water fish (Tilapia nilotica) were collected from El-Gharbia and Kafr El-Sheikh Governorates (90 of $\overline{\text { Kafr El-Sheikh Vet. Med. J. Vol. } 1 \text { No. } 1 \text { (2003) }}$ 
I.Aman

each), samples were placed in clean sterile plastic bags and transferred, without delay to the laboratory under aseptic conditions and then subjected to the following examinations:

\section{II.Mycological examination:}

A.Preparation of the samples according to (APHA, 1985).

B.Determination of total mould and yeast count according to Cruickshank et al. (1975).

C.Isolation of mould and yeasts from the examined samples:

1.Identification of isolated mould according to (Zycha et al.,1969, Samson, 1979 and Pitt and Hocking, 1985).

2.Identification of isolated yeasts:

\section{*Morphological examination:}

1.Growth on Sabouroud dextrose agar according to (Finegold and Martin, 1982).

2.Vegetative reproduction using rice agar medium according to (Rohde et al., 1980).

\section{*Physiological examination:}

1- Pellicle formation according to Harrigan and McCance (1976).

2- Sugar fermentation according to Lodder and Kreger van (1970).

3- Urease Test: according to Cruickshank et al. (1975).

Table 1:Incidence of total mould and yeast counts of Tilapia nilotica in ElGharbia and Kafr El-Sheikh Governorates.

\begin{tabular}{|c|c|c|c|c|c|c|}
\hline \multirow{2}{*}{ Governorate } & \multirow{2}{*}{$\begin{array}{c}\text { No. of } \\
\text { samples }\end{array}$} & \multirow{2}{*}{$\begin{array}{l}\text { No. of positive } \\
\text { samples }\end{array}$} & \multirow{2}{*}{$\%$} & \multicolumn{3}{|c|}{ Statistics } \\
\hline & & & & Min. & Max. & Mean \\
\hline El-Gharbia & 90 & 40 & 44.4 & $1 \times 10$ & $25 \times 10$ & $5.5 \times 10$ \\
\hline Kafr El-Sheikh & 90 & 45 & 50 & $1 \times 10$ & $4.5 \times 10^{2}$ & $7.3 \times 10$ \\
\hline
\end{tabular}

$\overline{\text { Kafr El-Sheikh Vet. Med. J. Vol. } 1 \text { No. } 1 \text { (2003) }}$ 
Table 2: Incidence of isolated mould genera from the examined Tilapia nilotica samples from El-Gharbia Governorate $(\mathrm{n}=90)$.

\begin{tabular}{||l||c||c||}
\hline \multicolumn{1}{|c||}{ Mould } & No. of + ve samples & $\%$ \\
\hline \hline Alternaria spp. & 3 & 3.33 \\
\hline Mucor spp. & 8 & 8.89 \\
\hline Penicillium spp. & 22 & 24.44 \\
\hline Rhizopus spp. & 11 & 12.22 \\
\hline Cladosporium spp. & 9 & 10 \\
\hline Aspergillus spp.: & 20 & 22.22 \\
A. niger & 8 & 8.89 \\
A. ochraceus & 6 & 6.67 \\
A.fumigatus & 12 & 13.33 \\
A. terrusthom & 7 & 7.78 \\
\hline
\end{tabular}

Table 3: Incidence of isolated mould genera from the examined Tilapia nilotica samples from Kafr El-Sheikh Governorate $(n=90)$.

\begin{tabular}{|l|c|c|}
\hline \multicolumn{1}{|c|}{ Mould } & No. of +ve samples* & \%* \\
\hline \hline Alternaria spp. & 5 & 5.56 \\
\hline Mucor spp. & 13 & 14.44 \\
\hline Penicillium spp. & 18 & 20.00 \\
\hline Rhizopus spp. & 9 & 10.00 \\
\hline Cladoscporium spp. & 3 & 3.33 \\
\hline Aspergillus spp.: & 11 & 12.22 \\
flavus & 6 & 6.67 \\
niger & 4 & 4.44 \\
ochraceus & 2 & 2.22 \\
fumigatus & 8 & 8.89 \\
A. terrusthom & 3 & 3.33 \\
\hline
\end{tabular}

* From the total examined samples.

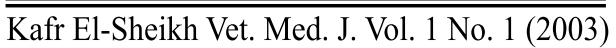


Table 4: Incidence of isolated yeasts from the examined Tilapia nilotica samples in El-Gharbia and Kafr El-Sheikh Governorates $(\mathrm{n}=90)$.

\begin{tabular}{||l|c|c|c||c||}
\hline \multirow{2}{*}{ Isolates } & \multicolumn{4}{c||}{ Governorates } \\
\cline { 2 - 5 } & \multicolumn{2}{|c|}{ El-Gharbia } & Kafr El-Sheikh \\
\cline { 2 - 5 } & No. & $\%$ & No. & $\%$ \\
\hline \hline Candida spp. & 15 & 16.67 & 22 & 24.44 \\
\hline Cryptococcus spp. & 8 & 8.89 & 3 & 3.33 \\
\hline Torulopsis spp. & 15 & 16.66 & 28 & 31.11 \\
\hline Trichosporum spp. & 7 & 7.78 & 19 & 21.11 \\
\hline Rhodotorula spp. & 16 & 17.78 & 0 & 0 \\
\hline \hline
\end{tabular}

\section{DISCUSSION}

Fish subjected to many risks of contamination from different sources during fishing, marketing till reaching to consumer the chief sources of fish contamination are water, soil, sewage, workers and equipments, such contamination communally render the fish and their products unfit for human consumption, causing severe economic losses and public health hazards to consumers (National Academic of Sciences, 1985).

The results recorded in Table (1) revealed that 40 (44.4\%) out of 90 fish samples collected from El-Gharbia Governorate were contaminated with mould and yeasts, with a mean value $5.5 \times 10$, while higher results were recorded in samples collected from Kafr El-Sheikh Governorate, where $45(50 \%)$ of 90 fish samples were contaminated by mould and yeasts, with a mean value $7.3 \times 10$ mould and yeasts/g of samples. Such variation may resulted from the different levels of sanitation and hygiene during rearing catching, marketing, and handling of fish (Frazier and Wasthoff, 1983 and Ward and Baaj, 1988). Relatively higher results were reported by Safaa (1999) who stated that the total mould and yeasts counts were $3 \times 10^{2} \mathrm{~g}$.

$\overline{\text { Kafr El-Sheikh Vet. Med. J. Vol. } 1 \text { No. } 1 \text { (2003) }}$ 
Moreover Table (2) showed that the incidence of mould species isolated from fresh water fish samples (Tilapia nilotica) which collected from El-Gharbia Governorate were Alternaria spp. (3.33\%), Mucor spp. (8.89\%), Penicillium spp. (24.44\%), Rhizopus spp. (12.22\%), Cladosporium spp. (10\%) and Aspergillus spp. (22.22\%). Further identification of Aspergillus spp. were $8.89 \%$ for A. niger; $6.67 \%$ for $A$. ochraceus; $13.33 \%$ for A. fumigatus and $7.78 \%$ for A. terrusthom.

Regarding the results recorded in Table (3) the incidence of isolated mould species collected from Kafr El-Sheikh Governorates were Alternaria spp. (5.56\%), Mucor spp. (14.44\%), Penicillium spp. (20\%), Rhizopus spp. (10\%), Cladosporium spp. (3.33\%) and Aspergillus spp. (12.22\%). The incidence of Aspergillus spp. member were further identified as A. flavus (6.67\%), A. niger (4.44\%), A. ochraceus $(2.22 \%)$, A. fumigatus (8.89\%) and A. terrusthom (3.33\%). Such variation between the percents of different mould isolated from El-Gharbia and Kafr ElSheikh samples may be attributed to the variation in the sanitary measures adopted during handling, catching and marketing of such fish.

Relatively higher results were recorded by Ali (1994) and Mohamed (1994) and Hala (2000) who could isolated the same organisms but in higher percent from fresh water fish the fungal growth produce toxic metabolites (mycotoxins) which lead to mutagenic, carcinogenic and teratogenic effect on human health (El-Shinawy et al., 1994). While some species of genus penicillum may induce pulmonary infection, mycotic keratitis and endo carditis (Washington, 1981). So hygienic rearing, catching, marketing, preparation of fish can greatly reduce the counts of mould and yeasts consequently protect human health from such hazard induced by such pathogens (Safaa, 1999).

Table (4) revealed that the incidence of isolated yeasts from ElGharbia and Kafr El-Sheikh Governorates were $16.67 \%$ and $24.44 \%$ for Candida spp. $8.89 \%$ and $3.33 \%$ for Cryptococcus spp., $16.67 \%$ and $31.11 \%$ for Torulopsis spp.; $7.78 \%$ and $21.11 \%$ for Trichopsorum spp. and $17.78 \%, 0 \%$ for Rhodotrula spp. such great variations between Governorates may be attributed to the climatic conditions as well as soil Kafr El-Sheikh Vet. Med. J. Vol. 1 No. 1 (2003) 
I.Aman

nature which is considered as an important reservoir for yeasts, which can survive under variable conditions and can be disseminated into food (Shaltout and Edris, 1999). Candidda albicans is a dengeros yeast which can lead to sever problems to human as thrush and dermatitis. while Trichosporon spp. may be led to invasion of mucous membrane and skin, Cryptococcus is communally accompanied with depletating disease as leukemia and lymphoma as recorded by Washington (1981) and Finegold and Martin (1982).

\section{ACKNOWLEDGEMENT}

The study was supported in part with the federal funds from Tanta Univ. under contract "Monitoring of environmental pollution of foods of animal origin in ElGharbia and Kafr El-Sheikh Governorates" of Code No. 392.

\section{REFERENCES}

- Ali, M.N. (1994): Studies on bacterial and mycotoic affection of fresh water fishes in aquaculture Ph.D. Thesis, infectious disease, Fac. vet. Med. Cairo University.

- American Public Health (APHA, 1985): Compendium of methods for the microbiological examination of food. The American Public Health Association, Speck, M.L. (Ed.) $2^{\text {nd }}$ Washington, D.C.

- Bullerman, L.B. (1979): Significance of mycotoxins to food safty and human health. J. Food Prot. 42(1): 65-86.

- Connel, J.J. (1990) : Control of fish quality. Fishing News Books, p. 85-88.

- Cruickshank, R.; Duguid, J.P.; Mavmion, B.P. and Swain, R.H.A. (1975): Medical microbiology, 11rh Ed., E. and S. Livingstone Limited Edinburg and London.

- El-Shinawy, S.H.; Abd El-Aziz; A.M. and El-Hady, H.A. (1994): Microbilogical quality of infant powdered milk. J. Egypt. Vet. Med. Ass. V. 55 (1, 2): 147-154.

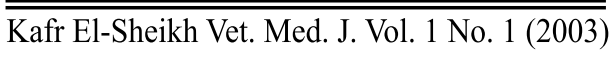


I.Aman

- Finegold, S.M. and Martin, W.J. (1982): Diagnostic Microbiology. $6^{\text {th }}$ Ed.

- Frazier, W.C. and Westhoff, D.C. (1983): Food Microbiology $3^{\text {rd }}$ Ed. Tata McGrow Hill Book Company Limited, New Delhi, India.

- Hala, A.M. (2000): Incidence of fungal contaminants in fish and fish products. Ph.D. Thesis. Dept. Food Hygiene. Zagazig University.

- Harrigan, W.R. and McCance, M.E. (1976): Laboratory methods in food and dairy microbiology. Academic Press, Inc. (London), Ltd. Great Britain.

- Lodder, J. and Kreger, Van. RIJ, (1970): The yeasts A. Taxonomic Study. North Holland Publishing Company Amsterdam.

- Mohamed, N.A.E. (1994): Some studies on mycoflora of fresh water fish with special reference to Aspergillosis. Ph..D. thesis Dept. of Animal Medicine, Fac. Vet. Med. Assiut. University, Egypt.

- National Academic of Sciences (1985): An evaluation of the role of microbiological criteria for foods and food ingredients. National Academy Press, Washington, D.C.

- Pitt, J.I. and Hocking, A.N.D. (1985): New species of fungi from Indonesian dried fish. Mycotaxon, 22: 197-208.

- Rippon, T.W. (1982): The pathogenic fungi and pathogenic actinomyces "Medical Mycology" $2^{\text {nd }}$ Ed. Philadelphia WB Sounders.

- Rohde, B.; Hartman, G.; Haude, D.; Kessler, H.J. and Langen, M.L. (1980): Introducing mycology by examples. Hamburg Schering, A Ktiengesellschaft.

- Safaa, S.T. (1999): Mycological contamination of some fish products at Alexandria Province. M.V.Sc. Thesis, Dept. Food Control. Fac. Vet. Med. Alexandria University.

- Samson, R.A. (1979): A complication of the Aspergillus described since (1965). Studies in mycology, Baarn, 18: 1-8.

$\overline{\overline{\text { Kafr El-Sheikh Vet. Med. J. Vol. } 1 \text { No. } 1 \text { (2003) }}}$ 
I.Aman

- Shaltout, F.A. (1996): Mycological and mycotoxicological profile of some meat products. Ph.D. Thesis, (meat Hygiene). Fac. Vet. Med. Moshtohor, Zagazig University. Benha branch.

- Shaltout, F.A. and Edris, A.M. (1999): Contamination of shawerma with pathogenic yeasts. Assut. Vet. Med. J. (41): 170-176.

- Ward, D.R. and Baaj, N.J. (1988): Factors affecting microbiological quality of seafoods. Food Technol., 42(3): 85-89.

- Washington, J.H. (1981): Laboratory procedures in clinical microbiology. Springer Verlag New York, Inc.

- Wilson, N.R.P.; Dyett, E.J.; Hughes, R.B. and Jones,

C.K.V.(1981): Meat and Meat products. Applied Science Publisher,London, and New Jersey,90.

- Zycha, H.; Siepmann, R. and Linnemann, G. (1969): Mucorales. Ene Beschreibung-aller. Gattungen and Arten Diesser Pilzgruppe Verlage Von D. 3301 Lehre J. Cramer.

$$
\begin{aligned}
& \text { الوجهه الميكولوجيه لاسماك المياة العذبة } \\
& \text { نادر يحيى مصطفى - قسم الرقابة الصحية على الاغذية } \\
& \text { ابراهيم محمد امان كلية الطب البيطرى بكفرالثيخ - جامعة طنطا }
\end{aligned}
$$

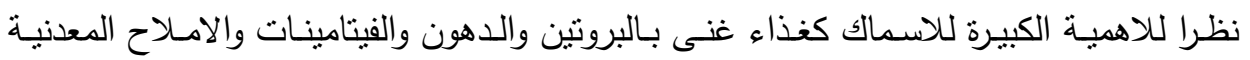

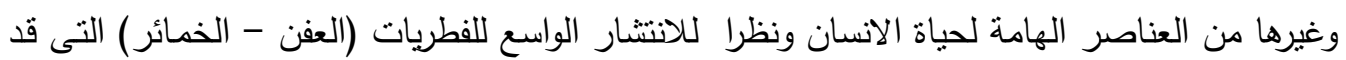

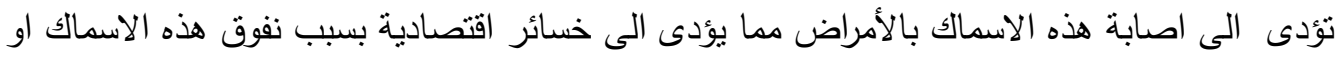

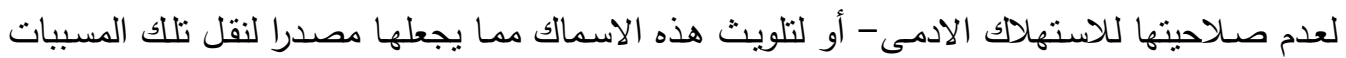

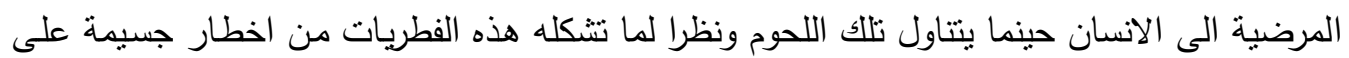
صحة الانسان بسبب قدرتها على افراز سمومها الفطرية. لذلك اجريت هذه الدراسة على لحوم اسماك الك الكان

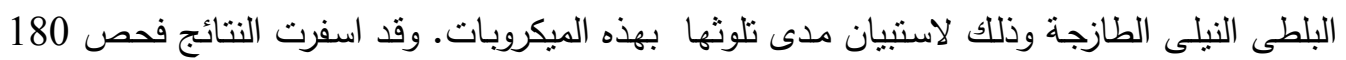

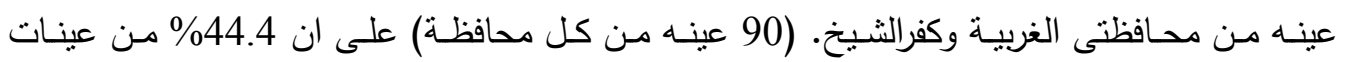

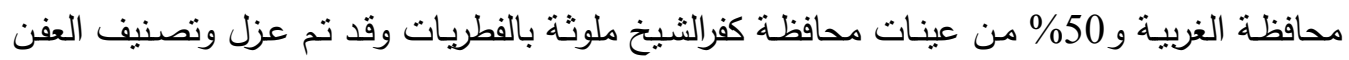
والخمائر الموجودة بالعينات وكانت كالاتى: 1 - 1 العفن:

- الترناريا (Alternaria spp.) ، ميكور (Mucor spp.)

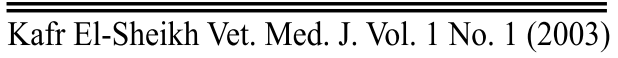




$$
\text { - بنيسليوم (Penicillium) ، ريزوبس ( (Rhizopus spp). }
$$

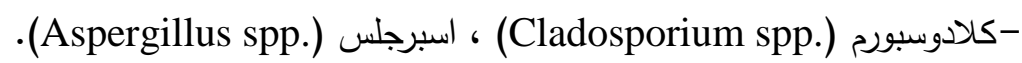

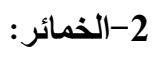

كانديـا (Candida spp.

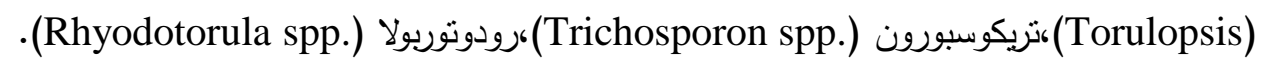

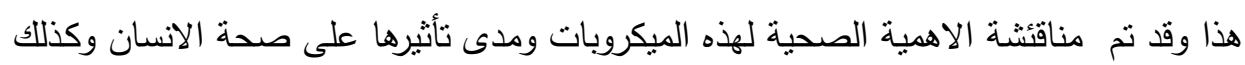

الاجراءات الواجب اتخاذها لتقليل التلوث بها بهدف الحصول على غذاء سليم آمن.

$\overline{\overline{\text { Kafr El-Sheikh Vet. Med. J. Vol. } 1 \text { No. } 1 \text { (2003) }}}$ 